\title{
GERMAN DEMOCRATIC REPUBLIC OF THE 1970s-1980s THROUGH THE EYES OF SOVIET OFFICERS (ORAL STORIES)
}

\author{
Evgeny V. Volkov \\ Department of Russian and Foreign History \\ South Ural State University, Russia \\ e-mail:evgeny-volkov@mail.ru
}

\begin{abstract}
This article is based on eight interviews with former officers who served in the Group of Soviet Forces in Germany (after 1989, the Western Group of Forces) during the $1970 \mathrm{~s}$ and $1980 \mathrm{~s}$. The aim of this research is to analyze the content and speech characteristics of Soviet officers' oral testimonies about their service in the German Democratic Republic (GDR). The main task of this research is to study information about the conditions of service of Soviet officers in the GDR, identifying key images of East Germany in the views of the respondents, and describing individual and general features of the respondents' discourse. The reminiscences about the GDR presented in the interviews reveal the different attributes of social memory of the former Soviet military personnel, who usually had positive stories to tell about their years spent in the country. The discourse of the respondents who were interviewed had some common features inherent in the identity of a "military man": efficiency and clarity of speech, emphasizing the positive characteristics of the Soviet Army, and the absence of criticism of the Soviet authorities. At the same time, many memories included negative evaluations of the policies of President Boris Yeltsin and feelings of nostalgia for life in the Soviet Union.
\end{abstract}

Keywords: German Democratic Republic, Group of Soviet Forces in Germany, intercultural communication, oral stories, Soviet officers, Western Group of Forces

\section{THE FORMULATION OF THE ISSUE}

Intercultural communication, the result of constructed representations about the people and cultures of other countries, helps to form opinions and evaluations and influences styles of behavior. The history of the Soviet troops in East Germany from 1945 to 1994 has recently become the subject of intense study for a number of German historians (Kowalczuk \& Wolle 2001; Satjukow 2008; Hoffmann \& Stoof 2008; Gehrke 2008; Lohmann 2010; Büttner \& Morre 2014). ${ }^{1}$ Modern Russian historiography on the subject is not as extensive and 
includes only a few works mainly created as political history and usually based on personal memoirs (Burlakov 1994; Boltunov 1995; Basistov \& Ezhova 2005). However, in my opinion, the most productive research can be undertaken by means of a historical-anthropological approach that addresses not only specific events and impressions of those events, but also the thoughts and emotions of people, their life practice. The most promising direction in the field of history is the study of intercultural communication (Satjukow 2003; Zdravomyslov 2003; Vershinin 2003; Tikhomirova 2008).

In this research, which is based on oral history interviews and several published memoirs, journalistic texts and documents of the Group of Soviet Forces in Germany (the Western Group of Forces), the following questions are raised: What were the conditions of service of Soviet officers in the German Democratic Republic (GDR)? What were the forms of international communication between the Soviet officers and Germans? What images of East Germany remained in the memories of Soviet officers? How did service in the GDR influence the opinions of Soviet officers?

I think such research will increase knowledge in the study of representations constructed by Soviet officers about East Germany during the Cold War.

The oral stories can be considered memory markers about the past. According to the theory of the German researchers Jan and Aleida Assmann, "collective memory" is a group of representations about the past, captured in images that are constructed in the form of social and cultural memory. Social memory is based on the communication of people as witnesses and contemporaries of the recent past (Assmann 2004: 14-91; Assmann 2014). From this point of view, oral stories are social memories as representations of a certain group of people about their recent past.

\section{HISTORICAL CONTEXT}

Relations between the Union of Soviet Socialist Republics (USSR) and the GDR were built in a more intensive manner than in other socialist countries of Eastern Europe. One major factor was the overall experiences, both negative and positive, of World War II (Eimermacher \& Volpert 2010). Military cooperation, in addition to economic and cultural cooperation, was most ambitious in the GDR. The biggest deployment of Soviet troops from 1945 to 1994 was in the territory of the GDR. During a period of almost fifty years 540,000 officers, 180,000 warrant officers, and 5,380,000 soldiers and sergeants served in the Group of Soviet Forces in Germany. We must add 416,000 workers and employees, as well as 1,500,000 members of officers' families. As a result, more than eight million Soviet citizens lived, served, and worked in East Germany from 1945 
to 1994 (Boltunov 1995: 100). The Group of Soviet Forces in Germany was like a small country, with its own supply system, equipment repair, schools, rest homes, and even a radio station and a theater (Basistov \& Ezhova 2005: 175).

The period from the second half of the 1960s to the middle of the 1980s was characterized by a great deal of activity in the relations between the Soviet Union and the GDR. At that time the Soviet leadership began giving more freedom to the GDR. The semi-enemy image of East Germany in Soviet propaganda gradually became more positive after the construction of the Berlin Wall (1961) (Vatlin 2009: 186-187).

We can point to a number of agreements signed between the Soviet Union and the GDR as important examples of cooperation. In 1969 a visa-free regime was introduced between the two countries (Zemskov 1981: 245-248). SovietGerman relations were even confirmed at the level of the new Constitution of the GDR in 1974, which said that East Germany "forever and forever is an ally of the Soviet Union" (Faulenbach 2009: 94). Perhaps this was the reaction of the GDR's leadership to the Kremlin's giving more freedom to East Germany.

On October 7, 1975, the agreement "Friendship and Mutual Assistance between the USSR and the GDR" was signed. On September 3, 1978, the joint space flight of Vladimir Bukovsky and Sigmund Yen ended, the latter being the first German to fly in space as part of the Soviet Intercosmos program. At the end of the 1970s several Soviet military divisions left East Germany (Boltunov 1995: 89).

In 1976, at the 11th Congress of the Socialist Unity Party of Germany, the aim was established to construct a developed socialist society as in the Soviet Union. At this point in the relationship between the two countries, an equal union was established, replacing the "teacher - disciple" scheme (Vershinin 2003: 348). However, beginning in the middle of the 1980s, the attitude of the Germans to Soviet citizens who were in their country became more negative and even hostile (Zdravomyslov 2003: 378). The GDR leadership reacted negatively to the policy of Perestroika introduced in the Soviet Union. The Socialist Unity Party of Germany was more conservative and orthodox than the Communist Party of the Soviet Union (Faulenbach 2009: 94). However, most of the GDR's population apparently supported the new Soviet policy.

\section{RESPONDENTS}

There are not many published memoirs of Soviet officers who served in the GDR, though several Internet sites focus on the life of Soviet military men in East Germany (e.g. Gruppa Sovetskikh voisk v Germanii; Bernau v/ch 47545). My interest is in new sources of information, and therefore I used oral stories 
for the research, together with published memoirs. The interviews that became the basis for this research were conducted in the Chelyabinsk and Kurgan regions of the Russian Federation from April 2011 to May 2014. These interviews were thematic and contained a list of questions that became the main structure for interviewing respondents. The interviewees, former officers, were selected randomly. They told their oral stories at home or at the Russian History Department of South Ural State University. Two people took part in each dialog: a researcher and a respondent. The conversation usually lasted one hour.

Eight respondents shared their reminiscences about their service in the GDR. They were retired Soviet officers: four colonels, two lieutenant colonels, one major, and a captain. The distribution of the interviewees according to their specialization was as follows: four military drivers, two gunners, one tank troop, and one border guard. According to their social origin, four of the respondents considered themselves to be of white-collar family backgrounds, while the others regarded themselves as descendants of blue-collar workers. Almost all of the respondents were born in the Urals or in Siberia, and only one in the Volga Region. The average age of the respondents at the time of the interviews was sixty years. Seven of them had served in the GDR in the 1970s and 1980s, immediately after graduation from military schools, and one served in East Germany when he was older, in the rank of colonel. They were in the GDR for five years, except for one respondent, who was there for three years. A reduced service period took place, as a rule, if an officer was not married or received a bad evaluation. ${ }^{2}$

The speaking style of many respondents was clear and loud, typical of those used to giving orders. As a rule, these people were conservative. They regretted the collapse of the USSR; their words reflected nostalgia for the Soviet past and negative attitudes to Michael Gorbachev's liberal policy, as well as to Boris Yeltsin. They said little about the shortcomings of the Soviet Army, and more about the army's achievements and positive sides.

Such rhetoric can be explained by the fact that each social group needs "legitimation", which is achieved, among other ways, by drawing on certain shared rules and principles of communication. Such "legitimation" is carried out, according to the German philosopher Jürgen Habermas, on two levels. Firstly, the rules and principles of the "legitimation" construct a certain system of values. Secondly, this set of rules and principles serves as a basis for distinguishing between "us" and "them": those who adhere to these rules, and those who reject them (Habermas 2015 [2011]; Sladkova 2015: 13-14, 18-19). 


\section{FEATURES OF SOVIET OFFICERS' SERVICE IN THE GDR}

The Group of Soviet Forces in East Germany (up to March 24, 1954, the Group of Soviet Occupation Forces in Germany) was established on June 9, 1945, on the basis of military units of the 1st Belorussian Front, with headquarters in Potsdam. In 1946, the headquarters moved to Wünsdorf. At first the Group consisted of nine land and one aircraft army, and by the early 1950s this was reduced to seven armies. In 1979 one army withdrew from East Germany. It should be noted that beginning in the 1960s the Group of Soviet Forces in Germany was armed with rockets with nuclear warheads (Basistov \& Ezhova 2005: 173).

The Group of Soviet Forces in Germany was subordinated to the Commander of the Western Direction and cooperated with the National People's Army of the GDR. By the end of the 1980s, Soviet troops in the country amounted to nineteen divisions (eleven tank and eight motorized infantry). There were about 337,000 soldiers, more than 4,000 tanks, 7,500 armored vehicles, 3,600 artillery systems, 940 airplanes, and 785 helicopters. The troops were located on 777 bases; they had 3,422 training centers and shooting ranges, 47 airfields, and 5,269 depots and warehouses. In 1989, under the conditions of crisis in the Soviet system, all Soviet troops were renamed the Western Group of Forces, and began a gradual withdrawal from the territory of the GDR, which ended on August 31, 1994 (Feskov \& Kalashnikov \& Golikov 2004: 15).

Usually Soviet officers got the chance to serve in East Germany due to a tsarist era tradition that the Soviet Army continued. The highest achieving graduates of the military schools received first choice in place of the service. ${ }^{3}$ Many of the respondents, having excellent educational results, chose the GDR as their initial duty station.

What determined their choice? According to those interviewed, many of them dreamed about military service for nastoiashchikh muzhchin ('real men'). In contrast to the Soviet Union, where there were many incomplete military units and military exercises were seldom conducted, the Group of Soviet Forces in Germany engaged in diverse high combat training because they were stationed in the immediate vicinity of the enemy - the troops of NATO. ${ }^{4}$

Contemporary propaganda bulletins published by the political management of the Group of Soviet Forces in Germany served as constant reminders to Soviet soldiers that they were "the sentinels of the front line", on the border with the "militaristic Western World" (Liubit' rodinu 1960; Na boevom postu 1975; XXIV s"ezd KPSS 1971).

In addition, lieutenants could opt to serve in the GDR in order to boost their military careers. As a rule, officers who had served in the Group of Soviet Forces 
in Germany, upon their return to the Soviet Union received appointments one degree higher than they would have under normal circumstances (Basistov \& Ezhova 2005: 174). Yet, none of the respondents mentioned these advantages when explaining their aspirations and motives for serving in East Germany.

Material interests were another reason for the service in East Germany. Soviet officers abroad received a double salary, one in German marks at the place of service, and the other in Soviet rubles deposited in a savings account back in the Soviet Union. At the same time, it was possible to buy and then take home commodities that were difficult or impossible to find in the Soviet Union. There was an unwritten rule that during their final year of service in the GDR, Soviet officers bought many such things. ${ }^{5}$

Upon entering East Germany, the Soviet administration usually exchanged thirty rubles for GDR marks (ninety marks at the rate of 1976). In addition, each new officer received 200 marks during the first month. ${ }^{6}$ The average monthly salary of junior officers (lieutenants and senior lieutenants) was about 700 GDR marks, and they also received 300 marks to support the accompanying family. Service in the GDR was thus economically very beneficial. ${ }^{7}$ At the time, the average monthly salary in the Soviet Union was around 150 rubles or 450 GDR marks. In addition, many people certainly wanted to go abroad, to see other countries and learn about other cultures. As one respondent put it, "I wanted to see the West".

Before the trip to East Germany almost all of the respondents, being young officers, received preliminary instruction from political officers on how to behave abroad in order not to undermine the honor and dignity of Soviet citizens. Officers were strongly advised to avoid shopping and to control their wives, to abstain from contacts with Germans, and to obey their superiors. Single officers received strict commands not to pay frequent visits to restaurants and Gaststätte, and were instructed to drink moderately. ${ }^{9}$

It is worth noting that officers had to turn in their passports after their arrival in the GDR. When moving around in East Germany, they only had their identity papers with them. ${ }^{10}$ This measure was aimed at restricting Soviet officers' entry to East Berlin, where there were plenty of foreigners. Any Soviet citizen with a foreign passport could move on to West Berlin, which was considered a hostile territory. However, group trips of senior officers to West Berlin were allowed once a month. At first, such groups had to be accompanied by a command retinue, but by the 1970s these "bodyguards" were no longer required (Tolmachev 2010: 338-339).

There was a counter-intelligence officer in every military unit. He was usually called a "kgbshnik", ${ }^{11}$ referring to the Komitét gosudárstvennoi bezopásnosti (Committee for State Security) or KGB, the main security agency of the Soviet 
Union. Counter-intelligence officers had the task of monitoring the behavior and "illegal talks" of Soviet soldiers and officers, and interrogated people who had violated orders. One respondent noted that the counter-intelligence officer "always kept to himself in a group of officers. ... Usually he did not go to meetings with higher military authorities. But I got the impression that he knew everything". ${ }^{12}$ One of the most common punishments was premature departure to the Soviet Union for further service in northern garrisons. As a rule, such a situation undermined a successful future military career.

Soviet troops in the GDR were located in separate military camps near German settlements. Such military bases either had long histories, having been used before by troops of the German Empire or the Wehrmacht, or had been built only recently on the basis of German model projects. ${ }^{13}$ One of the respondents expressed his awe of the old military German buildings: "Amazing, they did everything on the highest level". ${ }^{14}$ Some homes occupied by the Soviet military had stucco and sculptures with Nazi symbols that had to be covered.

All military garrisons were surrounded by high fences, which were usually painted green, leading Germans to informally call the Soviet troops RussischGrün or "Green Russians" (Basistov \& Ezhova 2005: 179, 181). Practically the entire period of service of Soviet officers in the GDR was filled with intensive military training. Regimental, divisional, and army training exercises took place annually. Twice a year, usually for ten to twelve days, the Group of Soviet Forces in Germany conducted training with the participation of Polish and GDR troops (ibid.: 175). General Valentin I. Varennikov, who served in the GDR in a high command post, explained:

The Group of Soviet Forces in Germany was actually a school for preparing many staff members in all units of the Armed Forces of the USSR. Military training was carried out by the Group of Soviet Forces in Germany, together with the forces of the National People's Army of the GDR, which was tense and took place all year round. (Varennikov 2001: 4)

One of the respondents said: "We had a very fun life and we were not bored. There was an increase in the alarm level two or three times a week...". ${ }^{15}$ Every morning started with sports activities, and on Sunday all military units ran cross-country courses. Then there were theoretical and practical trainings for military people. The whole schedule was strict. ${ }^{16}$

Soldiers and sergeants, as a rule, arrived at the Group of Soviet Forces in Germany well prepared for such demanding service, as they had already passed the selection and primary military training in the USSR (Basistov \& Ezhova 2005: 174). The national composition of Soviet troops was multi-ethnic, including representatives of the many nations of the Soviet Union (Fig. 1). However, 


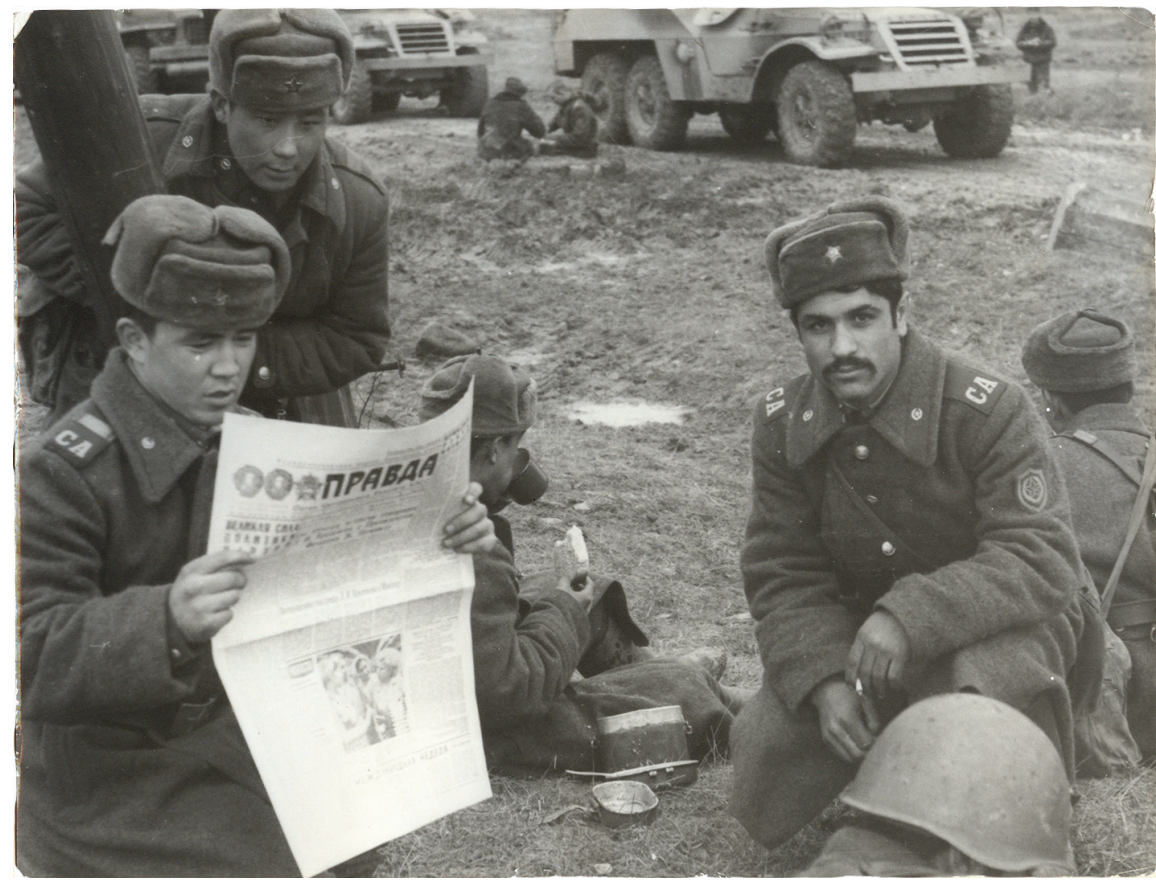

Figure 1. The multi-ethnic Soviet Army in the 1970s.

Photograph from the private collection of a respondent.

the largest groups were Russians and Ukrainians, followed by Armenians, Georgians, Azerbaijanis, Chechens, Tajiks, Uzbeks, and Latvians. ${ }^{17}$

Off-duty officers could go outside the military bases and communicate with the German population. Yet, this was discouraged and it was forbidden to move around in civilian clothes outside the bases (Basistov \& Ezhova 2005: 185). ${ }^{18}$ However, sometimes Soviet officers ignored it (Fig. 2). Individual trips by soldiers and sergeants in the GDR were forbidden. Except for certain cases, they were always on the military bases.

As for dedovshchina ('hazing'), many respondents admitted that it had taken place, although they discussed it with reservations and minimized this negative phenomenon in the Soviet Army. They pointed out that much depended on the commanders and how they controlled their soldiers. ${ }^{19}$ This is confirmed by the memoirs of one of the sergeants who served in the Group of Soviet Forces in Germany from 1984 to 1986 . His book contains facts that highlight "hazing with a slight touch of criminality" (Luchkin 2014: 20-22, 36-37, 43, 88-91). But some narrators noted that dedovshchina was not present in their military units and, on the contrary, experienced soldiers "had taken over all the hard work" and 
Figure 2. A Soviet officer in his free time in the GDR in the 1970s. Photograph from the private collection of a respondent.

taught young soldiers. ${ }^{20}$ Because of hazing and for other reasons, there sometimes were cases of desertion and crime among Soviet soldiers. However, such incidents were quickly suppressed in active cooperation with the GDR police.

Some respondents pointed out that some Soviet officers fled to the West, taking with them secret documents. But these incidents took place mainly at the end of the 1980 s and the beginning of the $1990 \mathrm{~s}$, when there was a crisis in the Soviet system and in the

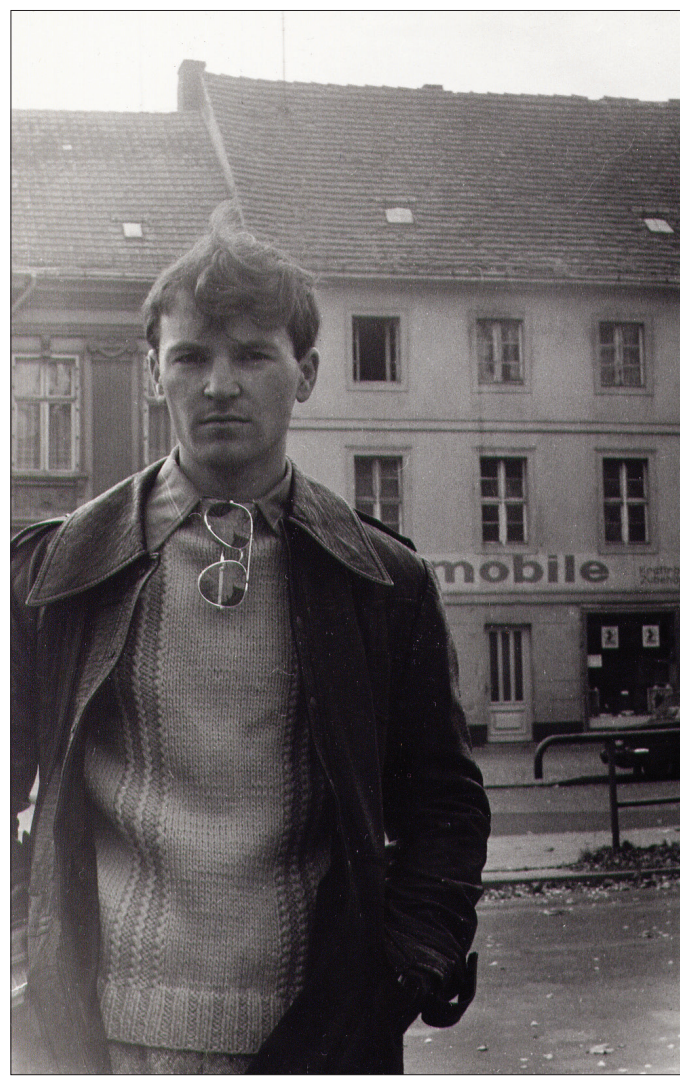
Soviet Army. ${ }^{21}$

Soviet officers usually spoke little about family life during their service in the GDR. Single lieutenants sought opportunities to get married quickly because this was a condition for extending their service abroad. There were also cases of adultery, but there were almost no divorces because they could lead to being sent back to the USSR. ${ }^{22}$ In general, many of the respondents had positive reminiscences about their service in East Germany. They had real combat training, improved their financial status, and got some knowledge of the German culture and the everyday life of Germans.

\section{THE FORMATS OF INTERCULTURAL COMMUNICATION}

According to the reminiscences of the interviewed Soviet officers, most of them were interested in getting to know East Germany, a country that was previously unknown to them. Only one of the interviewees was afraid to encounter Germans, who in Soviet war films were shown more as enemies than friends. ${ }^{23}$ 
Soviet military personnel could get information about Germans and their culture via formal channels, as well as informally, by engaging in direct contact with them. In the official discourse, firstly, there were propaganda texts. For example, beginning in 1961, every year a large collection of materials and documents about the GDR, designed specifically for Soviet officers, was published. It contained information about the economy, politics, and culture of the GDR, the main decisions of the Socialist Unity Party of Germany, excerpts from agreements between the Soviet Union and East Germany, and information about the National People's Army (Basistov \& Ezhova 2005: 179; Zhdanov 1975: 126).

In addition, twenty divisional newspapers and the central newspaper Red Army were periodically published in the Group of Soviet Forces in Germany. There was the radio station Volga, and a TV center was started in 1979 (Burlakov 1994: 228-229).

"The Room of German-Soviet Friendship" was another place where Soviet soldiers could find official information about the GDR. As a rule, such a room existed in each military unit and was used to display posters, photographs, albums, books, and pennants. It showcased everything about the GDR and friendly relations between Soviet citizens and Germans. Similar rooms were created in the military units of the National People's Army of the GDR. ${ }^{24}$

Informal communication with Germans took place mainly in shops, restaurants, Gaststätte, and in industries. Often, Soviet military men helped with agricultural labor on German cooperatives. ${ }^{25}$ German civilian builders worked on Soviet military camps and bases. A separate GDR construction company fulfilled the orders of the headquarters of the Group of Soviet Forces in Germany (Basistov \& Ezhova 2005: 176).

As mentioned above, joint military training exercises took place between the Soviet Army and the National People's Army of the GDR. There also were joint formal meetings and sports competitions (Khurbaev 1981: 52). ${ }^{26}$ Some officers pointed out the very high level of the Military Forces of the GDR (Varennikov 2001: 52-53). Soviet officers often went on excursions with their families and soldiers to see the most famous sights of East Germany.

Communication between the Soviet military and Germans was eased by the fact that many residents of East Germany knew the Russian language at the basic or intermediate level. One respondent said:

But I was convinced that language knowledge for me was not necessary, because the Germans already had great experience with our Russian people, and they perfectly understood everything we needed. And at any store, any Gaststätte, any restaurant, at the cashier, anywhere, if they saw that you were Russian, they were always ready to help. ${ }^{27}$ 
Many Germans were perceived as very friendly by Soviet military personnel. ${ }^{28}$ But perhaps this kindness was false and many Germans were simply fearful of the military power of the USSR. ${ }^{29}$

Soviet officers were not allowed to use their real last names in their dealings with Germans. Conversations with Western military personnel or with officers of foreign military missions in the GDR were strictly forbidden (Basistov \& Ezhova 2005: 186-187).

Although Soviet officers were not allowed to visit East Berlin on their own, there were a variety of loopholes in this prohibition. The interviewees had been there off duty and in civilian clothes and had seen many sights, including the Berlin Wall. ${ }^{30}$ Members of the Soviet military were advised not to leave their military units on days associated with the history of the Third Reich. One of these dates was April 20, the birthday of Adolf Hitler. On this day, as on other "Nazi holidays", noisy groups would gather in Gaststätte and restaurants, increasing the likelihood of acts of aggression against Soviet military personnel (Luchkin 2014: 201). ${ }^{31}$ One respondent remembered that a certain Gaststätte near his military base was notorious for being a "fascist place", as many former SS men frequented it. Of course, Soviet officers would not go there. ${ }^{32}$ According to the testimony of another respondent, there was hostility from German youth. One incident took place in the late 1970s, on the eve of Victory Day (May 9), when young German men defiled a cemetery for Soviet soldiers, throwing away wreaths and flowers, and painting swastikas on several monuments. ${ }^{33}$ Another interviewee recalled that during the second half of the 1980s the most negative reactions towards Soviet troops would come from German youth, although most young people were loyal to the Soviet military. ${ }^{34}$ But this was just the personal opinion of a former Soviet officer.

\section{IMAGES OF EAST GERMANY}

Certain images and recurrent tropes dominated respondents' oral accounts of East Germany. Firstly, German nature: well-groomed forests, fields and gardens, fruit trees growing everywhere along the roads. As one of the narrators noted, it was forbidden to pick fruit in public places. Exceptions were made only for pregnant women and children, and the police monitored the fruit trees closely. But sometimes Soviet soldiers would slyly drive their military trucks in such a way that the trucks would brush against the trees, causing fruit to fall into their vehicles. ${ }^{35}$

The forests in Germany, in comparison with the Soviet Union, were very clean, with no dead trees in sight and everything in perfect order. There were 
many living creatures, for example, rabbits and pheasants. Soviet officers often went into the forests near military units and hunted illegally. Sometimes it was possible to kill a wild boar. In order to fish on the rivers, lakes, and reservoirs of the GDR, one had to have a special permit, and even then one could only use fishing poles. However, Soviet officers and soldiers would fish with nets, sometimes during military trainings. ${ }^{36}$

Another recurrent image of Germany in the narratives of Soviet military men involved train stations. As a rule, Soviet officers would arrive in the GDR by train and they also often used trains to move around the country for service and personal travel. German train stations emerge from respondents' accounts as examples of German order. Many respondents pointed out the cleanliness and perfection of stations, the clarity of the whole system, and punctuality of the trains. For example, the Leipzig train station made a big impression on one of the respondents. ${ }^{37}$ Another person elaborated on the efficient work of the train station in Frankfurt on Oder. ${ }^{38}$ Some people were surprised that there were no sleeping cars on German trains. Typically, these trains were small, with only a few carriages. Soviet citizens would refer to them as "trams". The whole rail transport system was very different from that in the Soviet Union.

Another important attribute of Germany was the highway. Military vehicles were prohibited on such roads, but this rule was often violated. During military training exercises, Soviet convoys mostly used motorways to save time ${ }^{39}$ This was illegal, but local German authorities looked the other way. The respondents noted the high quality of German roads built from gravel and asphalt. The signage was colorful and the roads were marked clearly. In general, it was hard to get lost on the roads of East Germany. Even so, the officers still bought and used road maps. ${ }^{40}$

Almost all of the respondents mentioned the main cultural attractions of the GDR: the Dresden art gallery, Goethe's museum in Weimar, the Sanssouci palace in Potsdam, the Brandenburg gate in Berlin, and the Leipzig zoo. They had visited these sights either alone or with their families. They also mentioned the former concentration camps Buchenwald, Sachsenhausen, and Ravensbrück. Soviet military personnel often took part in official ceremonies for memorials dedicated to Soviet soldiers who had fallen in Germany during World War II. ${ }^{41}$ This was, of course, due to the historical policy of Soviet authorities and the anti-fascist rhetoric of the socialist German state (Fig. 3). Many of the excursions organized for military personnel were to memorial places connected with the history of the Third Reich and the Holocaust. For example, soldiers and sergeants of the Group of Soviet Force in Germany would pay collective visits to museums built on the sites of German concentration camps. 
Figure 3. Soviet officers during a military parade in the 1970s. Photograph from the private collection of a respondent.

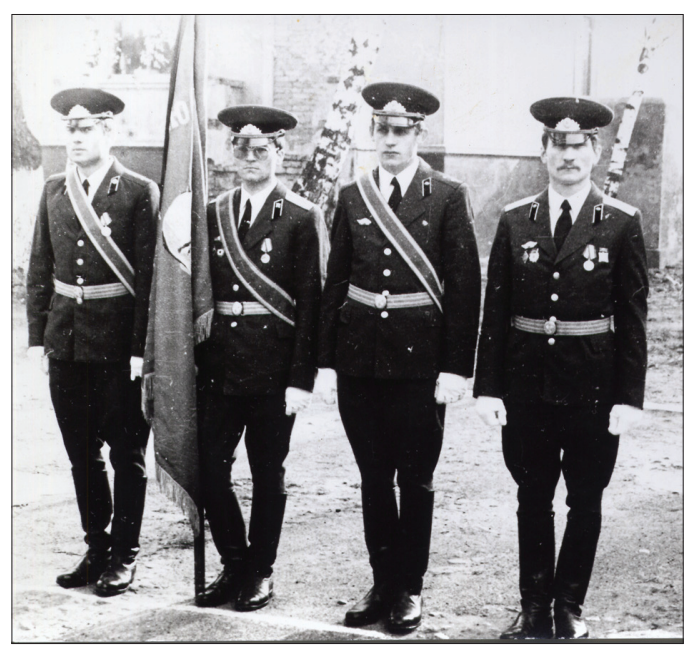

Another very significant image of the GDR in the minds of Soviet people concerned the shops and the abundance of goods, which stood in stark contrast to the situation in the USSR. The respondents talked about this in great detail. They noted the courtesy and friendliness of merchants, and the high level of service. German products and those of other foreign countries were of high quality, especially shoes and clothing. All of the products were available to officers of the Group of Soviet Forces in Germany and their family members. ${ }^{42}$ Some officers, according to one of the interviewees, were obsessed with shopping. ${ }^{43}$ At the same time, some Soviet people were amazed that Germans, who had been defeated in World War II, lived better than the Soviet victors. ${ }^{44}$

German cuisine was not particularly extolled by respondents. One of them negatively commented on "heavy" dishes and soups, which were more like sauces. ${ }^{45}$ However, many noted the excellent taste and variety of sausages with different spices. They also stressed the high quality of German beer, of which there was great variety. Under the influence of German cuisine, some officers even partially varied their diets while living in the GDR. For example, they drank more beer and Coca-Cola instead of the traditional tea. ${ }^{46}$

Formal and informal interactions with Germans led Soviet officers to form certain impressions of Germans and their culture. The respondents noted that Germans worked effectively and relaxed well. One of the narrators said that he heard from a German: "You live to work, and we work to live". ${ }^{47}$

The daily routine of the Germans was unusual for Soviet citizens. On the eve of working days, early in the evening, the streets and town squares were quiet. Germans stayed at home and went to bed early, because the next day 
they had to get up very early to go to work. At the same time, the working day ended at $4 \mathrm{pm}$, leaving Germans with plenty of free time before the evening. ${ }^{48}$

Since the respondents were men, they paid special attention to German women. They pointed out, for example, that Germans' attitudes towards sexual relations differed from that of the Soviet people. German women were said to be more relaxed in intimate relationships. The movies on the big screen and on TV very often showed erotic scenes, especially at night. While this might have been quite commonplace for Germans, it was unusual for Soviet citizens.$^{49}$ One of the respondents said that some Soviet citizens used the services of prostitutes.$^{50}$ Others spoke about the unenviable fate of officers who married German women, because this was detrimental to their military careers. ${ }^{51}$

A memorable figure representing East Germany was the policeman. The interviewees described him as a person the population was fond of, whom all inhabitants obeyed and who was always there to help. This situation contrasted sharply with the image of the police officer in the USSR. In the GDR, there was an efficient system whereby people could report information to the police and those who had committed crimes were, as a rule, quickly detained. In emergency situations, police patrols went out with dogs. Deserters from the Group of Soviet Forces in Germany were very often found by the German police. However, Soviet security police usually did not recommend that the Soviet military ask the German authorities for help..$^{52}$ The army did not inform the authorities of the GDR about criminals among Soviet soldiers. In their opinion, this could damage the prestige of the USSR. According to the interviewees, the police of the GDR consisted of specially selected and well-trained people. One respondent even said: "At that time people said that to become a policeman was as difficult as to fly into space". 53

Personnel of the National People's Army were closest in profession and spirit to Soviet officers (Fig. 4). Soviet and East German troops met through military training exercises and official celebrations, as well as sports competitions. GDR soldiers were attractive in the eyes of the respondents. They were usually dressed immaculately, clearly followed orders, and knew about complex military details. Even the equipment, weapons and uniforms of the National People's Army were aesthetically pleasing. The soldiers and officers of the GDR army seemed to have much more free time. After a day of work, they could go home and stay there till morning. ${ }^{54}$

These images of another country have been preserved in the memories of former Soviet military personnel, and we can assume that over time the memories have not been heavily distorted in the process of constructing reminiscences and biographical narratives. 


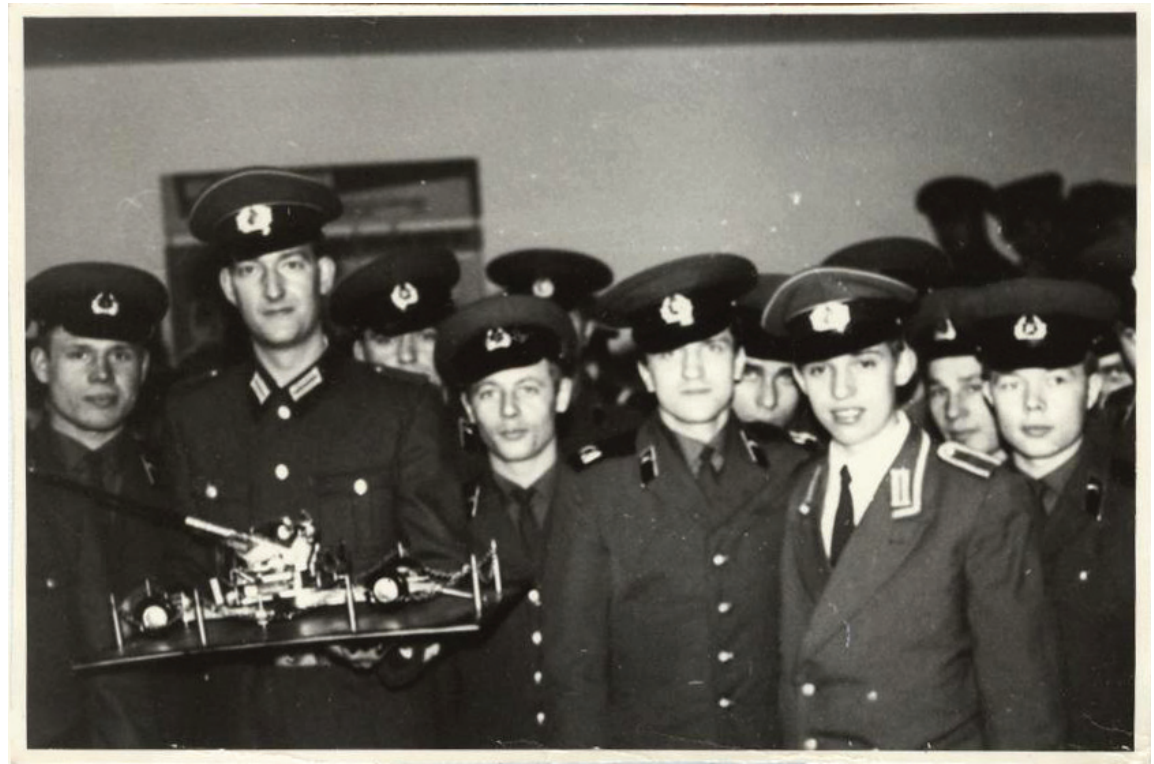

Figure 4. A meeting of soldiers from the USSR and the GDR in the 1970s. Photograph from the private collection of a respondent.

\section{CONCLUSION}

Oral stories told by eight former Soviet officers provided information on the life conditions of the Soviet military in the GDR and their views about the culture of East Germany. At the same time, these interviews demonstrated the attitudes and rhetoric of the respondents. They often emphasized the high efficiency of the Soviet Army, despite some of its shortcomings. They still believed in the positive mission of the Soviet Union in Eastern Europe during the Cold War. These oral stories included nostalgia for bygone times and youth in the "cozy and comfortable" ( $v$ uiutnoi i komfortnoi) East Germany. Images of Germans were often not the images of friends, but of people of another culture. However, the collective image of the "Other" constructed in the interviews was closer to the image of a friend than that of an enemy. But still, it was the image of a different culture. Representations of East Germany in these oral stories do not differ radically from written memoirs created by former officers and soldiers who served in the GDR (Tolmachev 2010).

These Soviet officers did not become active supporters of the democratic changes initiated in the Soviet Union during Perestroika, towards the end of the 1980s. On the one hand, there was the effect of the corporate conservatism 
of the military environment, and, on the other hand, these people saw in East Germany what might be called "socialism with a human face". The memories of the GDR, presented in oral stories, reveal the different attributes of the life world of former Soviet military personnel, which usually included positive biographical reminiscences about years spent in this country. They saw the Western world and learned something about Western culture. Many of them began their successful military careers in the GDR. It was a time of youth and the beginning of family relations. Their first children were born there. The families of these officers acquired many material goods in the GDR. The memories of these people included images of their service in the GDR, and on this basis they created a discourse about another country and a different culture. In many ways, these images were positive.

\section{NOTES}

1 See also the contribution by Christoph Lorke in this volume.

${ }^{2}$ Interview with Sh. V., May 2011.

${ }^{3}$ Interviews with K. G., April 2011, and Sh. V., May 2011.

${ }^{4}$ Interviews with A. S., November 2011, K. V., August 2011, and K. G., April 2011.

5 Interview with A. S., November 2011.

6 Interviews with K. G., April 2011, and A. S., November 2011.

7 Interview with S. V., May 2014.

8 Interviews with Sh. V., May 2011, and A. S., November 2011.

9 Interviews with K. G., April 2011, and A. S., November 2011.

${ }^{10}$ Interview with K. G., April 2011.

${ }^{11}$ Interview with K. V., August 2011.

${ }^{12}$ Interview with K. G., April 2011.

${ }^{13}$ Interviews with K. G., April 2011, K. V., August 2011, and Sh. V., May 2011.

${ }^{14}$ Interview with K. G., April 2011.

${ }^{15}$ Interview with A. S., November 2011.

${ }^{16}$ Interview with Sh. V., May 2011.

${ }^{17}$ Interview with K. G., April 2011.

${ }^{18}$ Interviews with K. G., April 2011, and Sh. V., May 2011. 
${ }^{19}$ Interviews with Sh. V., May 2011, K. V., August 2011, A. S., November 2011, and S. V., May 2014.

${ }^{20}$ Interview with E. V., December 2012.

${ }^{21}$ Interview with S. V., May 2014.

${ }^{22}$ Interview with K. V., August 2011.

${ }^{23}$ Interview with Sh. M., December 2012.

${ }^{24}$ Interview with Sh. V., May 2011.

${ }^{25}$ Ibid.

${ }^{26}$ Interviews with Sh. V., May 2011, and K. V., August 2011.

${ }^{27}$ Interview with K. G., April 2011.

${ }^{28}$ Interview with Sh. V., May 2011.

${ }^{29}$ Interview with Sh. M., December 2012.

${ }^{30}$ Interviews with K. G., April 2011, and Sh. V., May 2011.

${ }^{31}$ Interview with Sh. V., May 2011.

${ }^{32}$ Interview with K. G., April 2011.

${ }^{33}$ Interview with A. S., November 2011.

${ }^{34}$ Interview with S. V., May 2014.

${ }^{35}$ Interview with Sh. V., May 2011.

${ }^{36}$ Ibid.

${ }^{37}$ Ibid.

${ }^{38}$ Interview with K. G., April 2011.

${ }^{39}$ Interview with K. G., April 2011.

${ }^{40}$ Interview with A. S., November 2011.

${ }^{41}$ Interviews with K. G., April 2011, Sh. V., May 2011, K. V., August 2011, A. S., November 2011, E. V., December 2012, S. O., December 2013, and S. V., May 2014.

${ }^{42}$ Interviews with K. G., April 2011, Sh. V., May 2011, K. V., August 2011, and A. S., November 2011.

${ }^{43}$ Interview with K. G., April 2011.

${ }^{44}$ Interview with Sh. M., December 2012.

${ }^{45}$ Interview with K. V., August 2011. 
${ }^{46}$ Interviews with K. G., April 2011, Sh. V., May 2011, A. S., November 2011, and S. O., December 2013.

${ }^{47}$ Interview with A. S., November 2011.

48 Ibid.

${ }^{49}$ Interviews with Sh. V., May 2011, and K. V., August 2011.

${ }^{50}$ Interview with Sh. V., May 2011.

${ }^{51}$ Interviews with K. G., April 2011, K. V., August 2011, and A. S., November 2011.

${ }^{52}$ Interviews with Sh. V., May 2011, and A. S., November 2011.

${ }^{53}$ Interview with A. S., November 2011.

${ }^{54}$ Interviews with Sh. V., May 2011, K. V., August 2011, and A. S., November 2011.

\section{REFERENCES}

Assmann 2004 = Assman, Ian. Kul'turnaia pamiat': Pis'mo, pamiat' $i$ politicheskaia identichnost' $v$ vysokikh kul'turakh drevnosti. [Cultural Memory: Writing, Memory and Political Identity in the High Cultures of Antiquity.] Moscow: Iazyki slavianskoi kul'tury.

Assmann 2014 = Assman, Aleida. Dlinnaia ten' proshlogo: Memorial'naia kul'tura $i$ istoricheskaia politika. [The Long Shadow of the Past: Memorial Culture and Historical Policy.] Moscow: Novoe literaturnoe obozrenie.

Basistov \& Ezhova 2005 = Basistov, Iurii \& Ezhova, Galina. Pod znakom krasnoi zvezdy: Gruppa sovetskikh voisk v Germanii. 1945-1994 gg. [Under the Sign of the Red Star: The Group of Soviet Forces in Germany. 1945-1994.] St. Petersburg: Znanie.

Bernau v/ch 47545. [Bernau Military Unit 47545.] Available at http://bernau47545. com.ua/index.php?id=1, last accessed on September 12, 2017.

Boltunov, Mikhail 1995. ZGV: Gor'kaia doroga domoi. [WGT: The Bitter Way Home.] St. Petersburg: Shans. Available at https://www.e-reading.club/book. php?book=1009728, last accessed on September 12, 2017.

Burlakov, Matvei (ed.) 1994. Sovetskie voiska v Germanii 1945-1994: Pamiatnyi al'bom. [The Soviet Troops in Germany 1945-1994: Memorial Album.] Moscow: Molodaia gvardiia.

Büttner, Stefan \& Morré, Jörg 2014. Sowjetische Hinterlassenschaften in Berlin und Brandenburg. Berlin: Ch. Links.

Eimermacher \& Volpert $2010=$ Aimermakher, Karl \& Fol'pert, Astrid. Nemetskosovetskie / rossiiskie otnosheniia vo vremia 'kholodnoi voiny'. [German-Soviet / Russian Relations during the Cold War.] In: Karl Aimermakher \& Gennadii Bordiugov \& Astrid Fol'pert (eds.) Rossiia i Germaniia v XX veke, Tom. 3. Moscow: AIRO-XXI, pp. 9-11. Available at http://www.airo-xxi.ru/-2010-/315--------3---3\#01, last accessed on September 12, 2017. 
Faulenbach 2009 = Faulenbakh, Bernd. GDR mezhdu traditsiei "nemetskogo osobogo puti"' i sovetskim vliianiem. [The GDR Between the Tradition of Special German Path and Soviet Influence.] In: Roman Boldyrev (ed.) Vlast' $i$ obshchestvo $v$ usloviiakh diktatury: Istoricheskii opyt SSSR $i$ GDR 1945-1965. Materialy nauchnoprakticheskoi konferentsii. Arkhangelsk: Pomorskii universitet, pp. 90-99.

Feskov \& Kalashnikov \& Golikov 2004 = Fes'kov, Vitalii \& Kalashnikov, Konstantin \& Golikov, Valerii. Sovetskaia Armiia v gody 'kholodnoi voiny' (1945-1991). [The Soviet Army during the Cold War (1945-1991).] Tomsk: Tomskii universitet.

Gehrke, Thilo 2008. Das Erbe der Sowjetarmee in Deutschland: Eine Bild- und Texdokumentation. Berlin: Dr. Köster.

Gruppa Sovetskikh Voisk v Germanii. [The Group of Soviet Forces in Germany.] Available at http://www.gsvg.ru/vospomonania_veteranov/, last accessed on September 12, 2017.

Habermas 2015 [2011] = Khabermas, Iurgen. Ot kartin mira $k$ zhiznennomu miru. [From Pictures of the World to the Life World.] Moscow: Ideia-Press.

Hoffmann, Hans-Albert \& Stoof, Siegfried 2008. Sowjetische Truppen in Deutschland und ihr Hauptquartier in Wünsdorf 1945-1994: Geschichte, Fakten, Hintergründe. Berlin: Dr. Köster.

Khurbaev, Rustam 1981. Armiia - shkola moia. [Army - My School.] Moscow: DOSAAF.

Kowalczuk, Ilko-Sascha \& Wolle, Stefan 2001. Roter Stern über Deutschland: Sowjetische Truppen in der DDR. Berlin: Ch. Links.

Liubit' rodinu 1960 = Liubit' rodinu i nenavidet' ee vragov - patrioticheskii dolg sovetskikh voinov. [To Love the Motherland and to Hate Its Enemies - the Patriotic Duty of Soviet Soldiers.] Collection of articles. N.p.: Politicheskoe upravlenie GSVG.

Lohmann, Horst 2010. GSSD - Die Gruppe der Sowjetischen Streitkräfte in Deutschland 1945-1994: Ein historischer Abriss. Hoppegarten: E. Meißler.

Luchkin, Aleksei 2014. Davshie obeschanie ne davat'obeshchanii. [They Have Promised Not to Make Promises.] Shadrinsk: Shadrinskii Dom pechati.

Na boevom postu $1975=$ Na boevom postu: Kniga o voinah Gruppy sovetskikh voisk $v$ Germanii 1975. [On the Fighting Post: The Book about the Battles of the Group of the Soviet Forces in Germany.] Compiled by P. M. Rakitin \& V. B. Sias'ko. Moscow: Voenizdat.

Satjukow, Silke 2003. Sowjetische Streitkräfte und DDR-Bevölkerung: Tour d'horizon einer Beziehung. Deutschland Archiv, No. 3, pp. 414-428.

Satjukow, Silke 2008. Besatzer: 'Die Russen' in Deutschland 1945-1994. [Occupiers: The Russians in Germany 1945-1994.] Göttingen: Vandenhoeck \& Ruprecht.

Sladkova, Alena 2015. Problema sotsial'noi legitimatsii v zapadnoi filosofii vtoroi poloviny $X X$ - nachala XXI veka. [The Problem of Social Legitimation in the Western Philosophy of the Second Half of the 20th - Beginning of the 21st Century.] Dis. kand. filosof. nauk. Tverskoi Gosudarstvennyi Universitet. Available at http://avtoref.mgou.ru/new/d212.155.08/Sladkova/diss.pdf, last accessed on September 13, 2017.

Tikhomirova, Anna 2008. Ot Shraibikusa do 'indeitsev i kovboitsev': GDR v zhiznennom mire sovetskogo rebenka 1980-kh godov. [From Shraibikus to 'Indians and Cowboys': The GDR in Life World of the Soviet Child in the 1980s.] Neprikosnovennyi zapas, No. 2 (58), pp. 243-258. Available at http://magazines.russ.ru/nz/2008/2/ti21. html, last accessed on September 13, 2017. 
Tolmachev, Evgenii 2010. Nebesnyi strazh GSVG. [Heavenly Guardian of the GSFG.] Kaluga: Manuscript.

Varennikov, Valentin 2001. Nepovtorimoe. [Unrepeatable Past.] Vol. 3. Moscow: Sovetskii pisatel'.

Vatlin, Aleksandr 2009. Formirovanie obraza 'novoi Germanii' v sovetskoi propagande nachala 50-kh godov. [Formation of the Image of the 'New Germany' in the Soviet Propaganda of the Early 1950s.] In: Roman Boldyrev (ed.) Vlast' $i$ obshchestvo v usloviiakh diktatury: Istoricheskiiopyt SSSR i GDR 1945-1965. Materialynauchnoprakticheskoi konferentsii. Arkhangelsk: Pomorskii universitet, pp.172-187.

Vershinin, Sergei 2003. Obraz GDR v sovetskom massovom soznanii: k postanovke problemy. [The Image of the GDR in the Soviet Mass Consciousness: To the Formulation of the Problem.] Nauchnyi ezhegodnik Instituta filosofii $i$ prava UrORAN, Vol. 4, pp. 336-353.

Zdravomyslov, Andrei 2003. Nemtsy o russkikh na poroge novogo tysiacheletiia: besedy $v$ Germanii. [Germans and Russians at the Threshold of the New Millennium: Conversations in Germany.] Moscow: ROSSPEN.

Zemskov, Igor N. (ed.) 1981. SSSR - GDR. 30 let otnoshenii, 1949-1979: Dokumenty $i$ materialy. [The USSR - the GDR. 30 Years of the Relations, 1949-1979: Documents and Materials.] Moscow: Politizdat.

Zhdanov, Nikolai 1975. Tsennoe posobie. [Valuable Guide.] Voennyi vestnik, No. 6, p. 126. XXIV s"ezd KPSS 1971 = XXIV s"ezd KPSS: Al'bom nagliadnykh posobii. [24th Congress of the CPSU: Album with Posters.] Wünsdorf: Politupravlenie GSVG. 